\title{
Mobility, turnover and storage of pollutants in soils, sediments and waters: achievements and results of the EU project AquaTerra. A review
}

\author{
J.A.C. BARTH ${ }^{1 *}$, P. GRATHWOHL ${ }^{1}$, H.J. FOWLER ${ }^{2}$, A. BELlin ${ }^{3}$, M.H. GERZABEK ${ }^{4}$, G.J. LAIR ${ }^{4}$, D. BARCELó ${ }^{5}$,

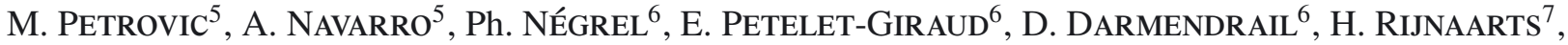 \\ A. LAngenhofF ${ }^{7}$, J. de WeErT ${ }^{7}$, A. Slob ${ }^{7}$, B.M. van der ZAAN ${ }^{7}$, J. Gerritse ${ }^{7}$, E. FranK ${ }^{8}$, A. GutierREZ ${ }^{6}$, \\ R. KretzSchmaR ${ }^{9}$, T. Gocht ${ }^{1}$, D. Steidle ${ }^{1}$, F. GARrido ${ }^{6}$, K.C. JoneS ${ }^{10}$, S. MEIJER ${ }^{10}$, C. MOECKEL $^{10}$,

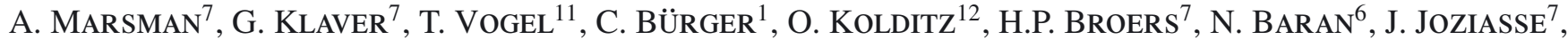

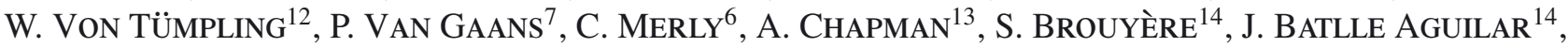 \\ Ph. ORBAN ${ }^{14}$, N. TAS ${ }^{15}$, H. SMIDT ${ }^{15}$

\footnotetext{
${ }^{1}$ Eberhard Karls Universität Tübingen, Center for Applied Geoscience, Sigwartstr. 10, 72076 Tübingen, Germany

${ }^{3}$ Università di Trento, Department of Civil and Environmental Engineering, Via Mesiano 77, 38050 Trento, Italy

${ }^{4}$ University of Natural Resources and Applied Life Sciences Vienna, Peter-Jordan-Strasse 82b, A 1190 Vienna, Austria

${ }^{5}$ Consejo Superior de Investigaciones Científicas, Instituto de Investigaciones Químicas y Ambientales de Barcelona, Jordi Girona Salgado 18-26, 8034 Barcelona, Spain

${ }^{6}$ Bureau de Recherches Géologiques et Minières, 3 avenue Claude Guillemin, BP 36009, 45060 Orléans, France

${ }^{7}$ Netherlands Organisation for Applied Scientific Research, PO Box 80015, NL 3508 TA Utrecht, The Netherlands ${ }^{8}$ Attempto Service GmbH, Karlstr. 3, 72072 Tübingen, Germany

${ }^{9}$ ETH, Department of Environment Sciences, Institute of Biogeochemistry and Pollutant Dynamics, CHN, 8092 Zürich, Switzerland

${ }^{10}$ Lancaster University, Environmental Science Department, Institute of Environmental and Natural Sciences, LA1 4YQ Lancaster, Great Britain

${ }^{11}$ Czech Technical University in Prague, Department of Hydraulic and Hydrology, Faculty of Civil Engineering, Thakurova 7, 16629 Prague, Czech Republic

${ }^{12}$ Umweltforschungszentrum Leipzig, Department of Inland water research, Department for aquatic chemistry and chemometrics, Brückstr. 3a, 39114 Magdeburg, Germany

${ }^{13}$ r3 Environmental Technology ltd, 88 Balmore Drive, Caversham, Reading, RG4 8NN, UK

${ }^{14}$ University of Liège, GEOMAC Department, Bât. B52/3 Chemin des chevreuils1, 4000 Liège, Belgium

${ }^{15}$ Wageningen university, Laboratory of Microbiology, Dreijenplein 10, 6703 HB Wagenirgen, The Netherlands
} \\ ${ }^{2}$ University of Newcastle, School of Civil Engineering and Geosciences, Cassie Building, Newcastle University, NE1 7RU Newcastle upon Tyne, Great Britain
}

(Accepted 5 December 2007)

\begin{abstract}
AquaTerra is one of the first environmental projects within the 6th Framework program by the European Commission. It began in June 2004 with a multidisciplinary team of 45 partner organizations from 13 EU countries, Switzerland, Serbia, Romania and Montenegro. Results from sampling and modeling in 4 large river basins (Ebro, Danube, Elbe and Meuse) and one catchment of the Brévilles Spring in France led to new evaluations of diffuse and hotspot input of persistent organic and metal pollutants including dynamics of pesticides and polycyclic aromatic hydrocarbons, as well as metal turnover and accumulation. While degradation of selected organic compounds could be demonstrated under controlled conditions in the laboratory, turnover of most persistent pollutants in the field seems to range from decades to centuries. First investigations of long-term cumulative and degradation effects, particularly in the context of climate change, have shown that it is also necessary to consider the predictions of more than one climate model when trying to assess future impacts. This is largely controlled by uncertainties in climate model responses. It is becoming evident, however, that changes to the climate will have important impacts on the diffusion and degradation of pollutants in space and time that are just at the start of their exploration.
\end{abstract}

contaminants / organic / inorganic / European river basins / climate change / sorption / biodegradation / soil / sediment / ground- and surface water / heavy metals / review / pesticides / atrazine / isoproturon / alkyphenol / acetochlor / chlortoluron / organochlorine / Br diphenyl ethers / drugs / TOF mass spectrometry / 87Sr

* Corresponding author: johannes.barth@uni-tuebingen.de 


\section{INTRODUCTION}

Europe has historically been a hotspot of environmental pressures and continues to be so because of its demographic and industrial developments. In order to better understand pollutant behaviour in a comprehensive way and meet the challenges of environmental impacts, the EU integrated Project AquaTerra was established. The full title of the project is "Integrated modeling of the river-sediment-soil-groundwater system; advanced tools for the management of catchment areas and river basins in the context of global change". The primary objective of this project is to lay foundations for a better understanding of the behavior of environmental pollutants and their fluxes with respect to climate and land use changes. Environmental topics cover a wide range of disciplines form about 250 researchers across Europe and the study areas are the catchments of the Ebro, Meuse, Elbe and Danube Rivers and the Brévilles Spring (Fig. 1).

The scales of investigation range from the laboratory bench to river basins and research results bear the potential to provide enhanced soil and groundwater monitoring as well as early identification and forecasting of impacts on water quantity and quality, and with that, improved river basin management. Within this context, the project performs research as well as modeling and quantifies deposition, sorption and turnover rates that lead to developments of numerical models. These include fluxes and trends in soil water and sediment functioning.

AquaTerra was one of the first environmental projects within the 6th Framework programme by the European Commission and counts among the largest environmental research projects worldwide. Work began in June 2004 and brought together a multidisciplinary team of 45 partner organizations from 13 EU countries, Switzerland, Serbia and Montenegro. The project has already made significant impacts to global environmental research within the first three years of its existence. For instance, close to 2000 environmental samples have been collected so far across Europe and, together with historical results and new environmental concepts, have led to close to 400 deliverable reports with novel environmental information. These reports make up about 9000 pages containing new information about pollutant behaviour in times of rapid environmental change. In part, these deliverable reports are made publicly available on the AquaTerra website that also provides constantly updated information at http://www.eu-aquaterra.de/. These together with the nonpublic deliverables are used as a basis for further scientific publications and high quality environmental databases. Publication activities are mostly documented by the so far $104 \mathrm{fi}-$ nalised peer-reviewed articles in internationally high ranking journals, 10 book chapters, and a large amount of public press appearances including TV, radio and newspapers (cf. reference list on AquaTerra website).

The AquaTerra team also just completed a special issue in the journal Environmental Pollution with the title "AquaTerra: pollutant behavior in the soil, sediment, ground, and surface water system" (Baborowski et al., 2007; Baran et al., 2007; Barth et al., 2007a; Bleeker and van Gestel, 2007; Bürger et al.,
2007; Graf et al., 2007; Hsu et al., 2007; Joubert et al., 2007; Kalbus et al., 2007; Klaver et al., 2007; Kolditz et al., 2007; Labandeira et al., 2007; Morasch et al., 2007; Petelet-Giraud et al., 2007; Poot et al., 2007; Rozemeijer and Broers, 2007; Slob et al., 2007; Vanbroekhoven et al., 2007; Vijver et al., 2007; Vink and Meeussen, 2007; Visser et al., 2007). This special issue covers topics including pollutant transfer from groundwater to surface waters, storage and turnover of heavy metals and persistent organic pollutants in soils and aquifers, recharge and climate change impacts. The global impact of the project is also maintained through special sessions at leading conferences. For instance the AquaTerra special session at the 9th International ConSoil conference in Bordeaux in October 2005 was heralded as a significant success and set trends for research and management directions in Europe. Another newly planned special workshop "Contaminant dynamics in periodically flooded soils" in the international Workshop at the EUROSOIL Congress in Vienna (August, 2008) is expected to have a similar impact on the environmental research community.

The large amount and diversity of information produced by AquaTerra, with its new results and investigation techniques, is worth a review in its own right. Even though often conducted at a local scale, results and techniques presented here are particularly important because new information can be transferred to other case studies elsewhere. Overall, AquaTerra is a good example of international collaboration, with scientific approaches extending across boundaries. In addition, the AquaTerra project is one of the few environmental projects to include socio-economic issues. This includes plans to link scientific results to stakeholder needs and policy makers. One of the central outcomes of the project is that environmental issues need to be evaluated for the system as a whole within interdisciplinary approaches.

\section{CONSORTIUM AND PROJECT STRUCTURE AND THEIR ORGANISATION}

The challenge of managing a large integrated project such as AquaTerra is met through the organisational structure of the project and its division into 11 sub-projects (Barth and Fowler, 2005; Gerzabek et al., 2007). The latter are again divided into work packages. For instance, the sub-project BASIN constitutes a research platform, which provides logistics for fieldwork and, in part, access to historical data from the Ebro, Elbe, Danube and Meuse Basins, and the Brévilles Catchment. Two other sub-projects, HYDRO and MONITOR, mainly provide new inputs of hydrological and chemical data through analyses of hydrological databases and models and chemical analyses and methods. These inputs are then taken up by the subprojects BIOGEOCHEM, FLUX, TREND and COMPUTE for laboratory tests and further evaluation of input, storage, turnover and exchange of pollutants between compartments as well as modelling of specific cases for water and contaminant transport. Potential global changes are then introduced into this systems modelling approach by the first work package in HYDRO, which produces scenarios of climate change 


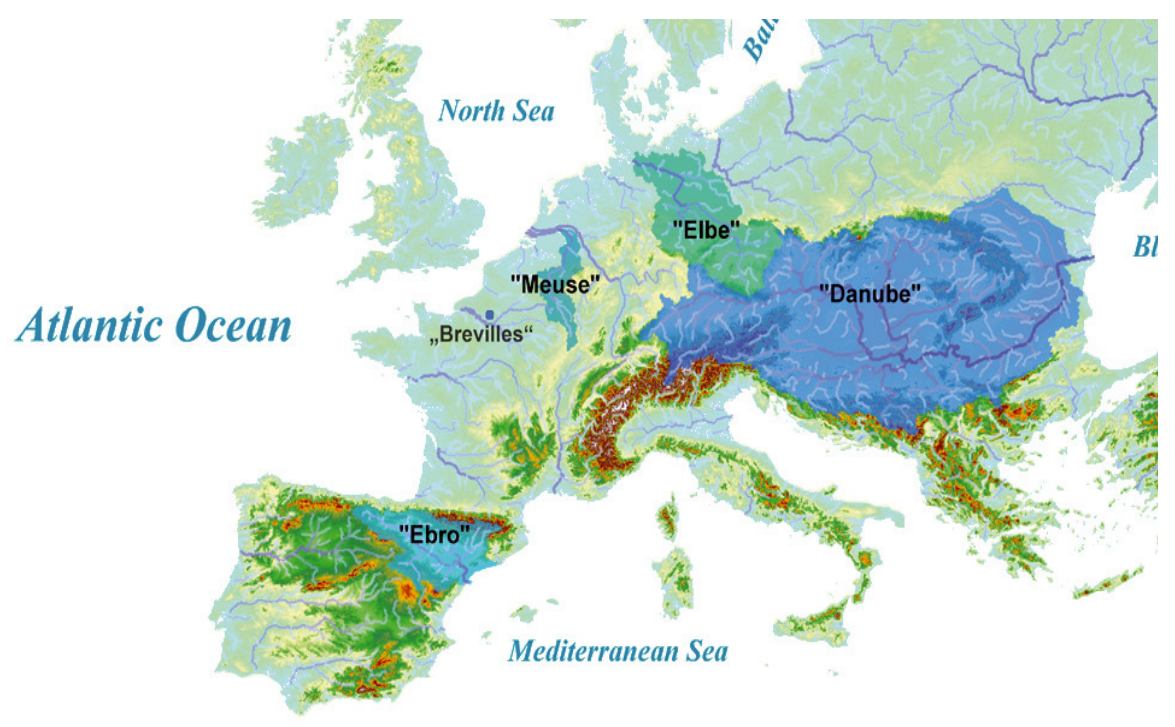

Figure 1. Basins and catchments of work within the AquaTerra project. Map by D. Kuntz.

so that their catchment-scale impacts can be better understood. Finally, socio-economic evaluations of such new results are then developed through conceptual models and recommendations in the sub-projects INTEGRATOR and EUPOL.

In order to maintain internal and external discussions of the project and to disseminate results, a separate subproject (KNOWMAN) has organised various courses covering topics on modelling, the fate of pollutants, socio-economic and legal aspects and environmental trends. This subproject also provides information on intellectual property rights as well as maintaining the AquaTerra public website. Between February 2006 and January 2007, 2311 Megabytes of data were uploaded to the website and user statistics show the broad and international perception of AquaTerra with users from New Zealand, Pakistan and Vietnam. A parallel internal web-based information forum (the AquaTerra Intranet) stores all relevant data and activities, which are continuously updated for availability to project participants.

To allow good functioning of the entire project, the subproject PROMAN is responsible for the management of AquaTerra, including reviews of reports, gender action plans and measures for integration. It acts as the interface between the European Commission and the project consortium in all financial and administrative issues and arranges the transferral of information and revised documents. This includes individual approaches to the partners as well as consultation by phone and e-mail. In addition, the logistics of regular AquaTerra meetings are organised by the PROMAN team and include the scientific technical realization of the work plan, reports and publications. This includes maintenance of a calendar for forthcoming and past events as well as a "Who is who" database that constitutes a useful overview of addresses and activities of project participants.

Overall, this structure is highly efficient for the conduct of environmental research that extends across boundaries and en- vironmental compartments. It enables an innovative and more thorough global understanding of the soil, sediment, ground and surface water system. Furthermore, the project structure provides excellent opportunities for all partners to gain high quality experience of state-of-the-art environmental methods in other laboratories across Europe. This is particularly exploited by young researchers, who on several occasions received scholarships to work in other counties based on their AquaTerra work.

\section{OBJECTIVES OF THE WORK AND GENERAL ACHIEVEMENTS}

With the fundamental mission of gaining improved understanding of the river-sediment-soil-groundwater system, participants focus on identifying relevant processes and quantifying their associated parameters. The study areas within Europe all have their own characteristics in terms of environmental concerns, climatological and demographic conditions. Within this context, the goal is to achieve a better understanding of pollutant dynamics in river basins as a whole to achieve potential transferral of results and techniques. This allows us to quantify the interaction and pollutant transfer between the various compartments (atmosphere, soils, sediments ground- and surface waters). New scientific results can then lead to improved environmental management tools and conceptual models for environmental planning on larger scales.

Selected achievements include:

- The establishment of fifteen new databases so far with hundreds of environmental parameters about specific environmental pollutants.

- Active links to other environmental projects. This is achieved through several avenues such as participation at 
other EU project meetings (RISKBASE, SWIFT, NORMAN, Harmoni-CA, Modelkey) and national activities as well as presenting AquaTerra at international conferences.

- International courses on unifying themes such as modeling and software demonstration, trends in the Elbe Basin, socioeconomic and legal issues and biogeochemical themes including sorption of organic pollutants versus biodegradation.

- Documents such as the AquaTerra Glossary (that explains more than 2000 specialist terms) to allow further integration within the project.

In the following section the key achievements will be listed grouped by sub-project. In all cases direct beneficiaries include the global environmental research community who receives new environmental monitoring and laboratory techniques together with highly relevant results and conclusions. For instance, AquaTerra has further developed high-resolution monitoring techniques such as passive samplers for ultra-low concentration measurements. Through these techniques it has become increasingly evident that most pollutants are ubiquitously present in the environment and, in many cases, stored for long time periods that range from decades to millennia. Other findings have confirmed that pollutants are often buffered by soils, while their mobility is mainly controlled by the aqueous phase such as ground- and/or surface water.

\subsection{Diffuse pollution and hotspots, logistics for fieldwork, provision of data in collaboration with other subprojects through the subproject BASIN}

Research in the Brévilles catchment focuses mainly on pesticides and their turnover in the subsurface (Baran et al., 2007; Morvan et al., 2006; Roulier et al., 2006). Work has led to an extensive database with chemical data, information on land use as well as a detailed description of the aquifer and hydrological setting. The Brévilles catchment belongs to a wider aquifer system of about $12 \mathrm{~km}^{2}$ that constitutes a closed system. The area has been investigated by questioning farmers about pesticide and fertilizer use, the installation of a total of 20 piezometers, tracer tests, microbiological investigations and the development of numerical models simulating water and material transport. The local spring, previously an important source for local water supply, was disconnected from the distribution network in August 2001 because pesticide and nitrate concentrations exceeded water quality limits. Continued research on this system shows that pesticides such as atrazine with an application ban in 1999 (4 years before the official ban in France) can be found with its metabolites in groundwater years after their application and in the spring without any significant decrease (Fig. 2). This suggests persistence and slow transport of this molecule and its related compounds in the subsurface. Scaling up such pollution problems to catchment and basin scales would likely cause even longer time periods for pesticide turnover in subsurface environments.

In the Ebro Basin, several detailed monitoring campaigns have been carried out since 2004 for ground- and surface water as well as sediment and soil samples (Eljarrat et al., 2004, 2005b; Lacorte et al., 2006; Lucas et al., 2006). This has led to analyses of a total of 70 contaminants. Focus was put on the determination of potential contamination sources including a textile industry, a tannery and several other production factories. The Flix risk area near Zaragoza initiated specific work for the study of novel dioxins and dioxin-like compounds in fish (Eljarrat et al., 2005a), while the contamination by new brominated flame retardants was monitored at the Cinca risk area. A comprehensive survey of pharmaceutical residues in the Ebro Basin included the monitoring of several pomible point sources (wastewater treatment palnts in Zarggosa, Logrõno, Pamplona, Lleida, Vitoria, Miranda, Tudela) (Gros et al., 2007). Another specific study was conducted by evaluating chemical and biological effects, including data interpretation of environmental hazards caused by pesticides on the water flea at the risk zone of the Ebro Delta (Barata et al., 2007). Work also included high-resolution statistical assessment with geographic information systems and led to several new publications about basin-wide pollutant evaluations (Navarro et al., 2006; Terrado et al., 2006; Terrado et al., 2007a, b).

In the Meuse Basin, new case studies applied a model predicting pore water composition in flood plain soils. The model includes an ecotoxicological module that models invertebrate and plant uptake. These studies revealed that risks depend mainly on the type of land use, habitat and key plant species (Bernhard et al., 2005; Vink and Meeussen, 2007). On the other hand, modern hydrogeological experiments at a pollution hotspot of a former cokery near Liège consisted of hydraulic- and tracer tests to quantify hydrodynamic and dispersive properties of the local alluvial gravel aquifer to evaluate groundwater fluxes at the aquifer-river interface. Together with results of bioassays and chemical analyses on sediments and suspended solids of sampling locations along the Belgian Meuse, this helped to estimate biogenic capacity and toxic effects (Morasch et al., 2007; Vanbroekhoven et al., 2007). Further groundbreaking work on the Geer sub-basin of the Meuse led to the prediction of mobility of pollutants and fertilisers over an entire catchment (Brouyère, 2006).

Work in the Elbe Basin has investigated the floodplains in the Czech Republic next to Les Kralovstvi Reservoir with re-suspended load that was polluted by mineral oil. Further downstream, near Magdeburg, sediments of floods were collected with novel trap mats to be further investigated together with soil samples. This revealed important new dynamics of pollutant transgression of contaminants such as cyclo- $\beta$ hexachlorohexane, a derivative of the herbicide lindane. At the same site, depth-specific soil water samples were collected for the determination of pollutant flux and transformations of organic and inorganic pollutants on the passage from soils via groundwater to surface water (Baborowski et al., 2007; Graf et al., 2007; Hsu et al., 2007). In the Bitterfeld region, other specific investigations of pollutant transfer on the passage from ground- to surface water were combined with piezometric and temperature measurements and an integral pumping test as well as isotope analyses to reveal only minor pollutant input through groundwater (Petelet-Giraud et al., 2007; Schmidt et al., 2006). This is an unexpected but 


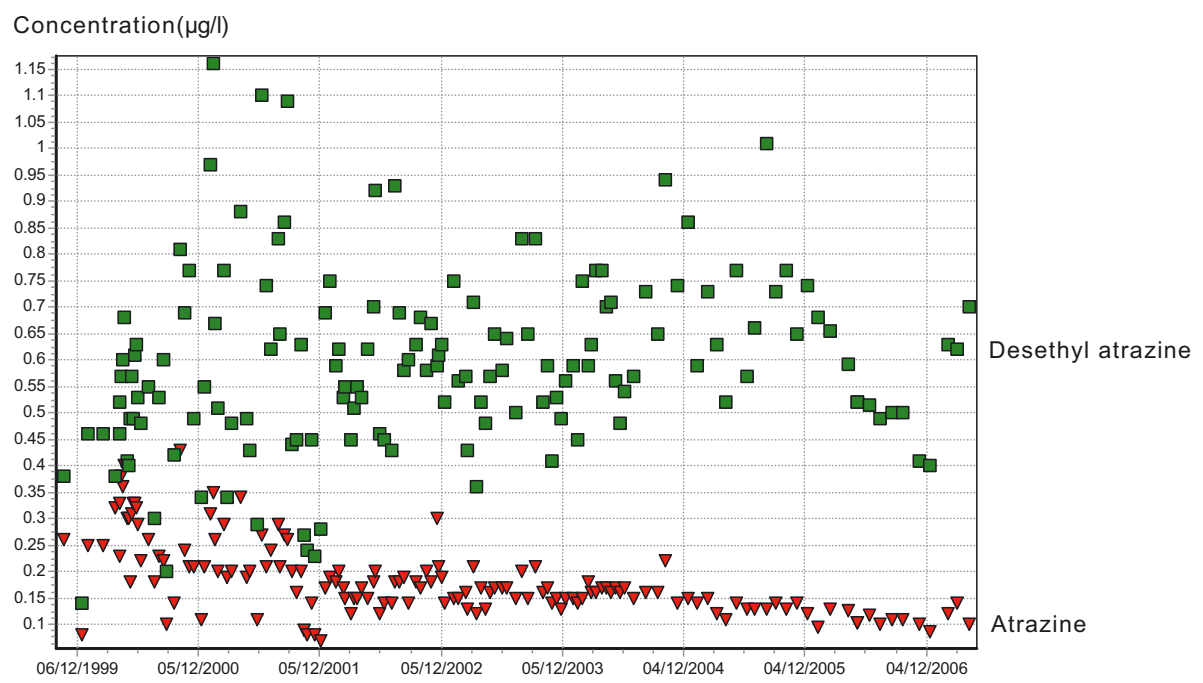

Figure 2. Atrazine and its metabolites at the Brévilles spring since end of spreading in 1999: Desethyl Atrazine does not show any significant decreasing trend. Monitoring from October 27, 1999 to April 12, 2007.

important result as an example for ground-surface water interaction that is central for the Water Framework Directive.

In the Danube Basin, the AquaTerra team completed a successful river sampling campaign on the main river in August 2004. This included the collection of sediments, water, fish and benthic organisms from 30 stations in 6 different countries along a $1150 \mathrm{~km}$-stretch of the river between Vienna and the Iron Gate Reservoir in Romania. This is not only a prime example of excellent European collaboration but also led to a highly complex database containing thousands of environmental results and has already led to a publication about sediment transport (Klaver et al., 2007). The work laid the foundations for further monitoring campaigns on the Danube. Further work in the Danube Basin has focused on atmospheric deposition of persistent organic pollutants (POP) and comparative soil investigations (Graf et al., 2007).

\subsection{Climatic variability and change, water balances, hydrological input data and their processing: the HYDRO sub-project}

The HYDRO team of AquaTerra have developed a framework for probabilistic scenarios of climate change for impact assessment and the reproduction of climate variable statistics using downscaling techniques (Fowler et al., 2007a). The methodology uses an assessment of climate model simulation of mean climate and extremes, such as droughts (Blenkinsop and Fowler, 2007a; Fowler et al., 2007a, c) and heavy rainfall (Fowler et al., 2007b) to weight model predictions of future change. In addition, rainfall modelling techniques have been further developed to integrate into the downscaling framework (Burton et al., submitted) and sophisticated methods have been produced to downscale in time from daily data, important for impact studies (Botter et al., 2007; Fowler et al., 2007a; Marani and Zanetti, 2007) This methodological framework is now being applied to the AquaTerra catchments in collabo- ration with numerical modellers in COMPUTE and TREND (Bürger et al., 2007). This involves links to selected impact studies (Fowler et al., 2007a) such as changes in drought frequencies in water supply regions of the UK (Blenkinsop and Fowler, 2007b). Key rainfall modelling deficiencies in large catchments have also been identified and improvements to optimization schemes have been made for models that were applied to the Gallego Catchment in the Ebro Basin (Bürger et al., 2007).

A more local climatic focus was placed on the Brévilles Catchment by assessing water inputs and monthly water levels in 20 established piezometers. One interesting feature of the climatic series is the progressive increase in rainfall from September 1995 to August 2000 and a subsequent decrease after 2000, which was also observed in the aquifer and the spring with a delay of two to three years. Further high-resolution geophysical investigations, tracer tests and determination of material properties were also carried out in the catchment and are currently being evaluated to constrain the subsurface hydrodynamics of this densely instrumented catchment.

\subsection{Novel analytical methods and their application with focus on emerging- and priority pollutants}

Several analyses were carried out on target priority and emerging contaminants for selected soil/sediment and water samples at temporal and spatial distributions relevant to the river basin scale and water as well as soil quality (Van Beusekom et al., 2006). They included priority compounds from the directives 2006/11/CE and 2455/2001/EC and comprised 20 organochlorine compounds, 8 polyaromatic hydrocarbons, 2 alkylphenols and 40 polybrominated diphenyl ethers congeners as well as various pesticides and metabolites and approximately 30 pharmaceutically active compounds (Eljarrat and Barcelo, 2006; Eljarrat et al., 2004; Lacorte et al., 2006; Ratola et al., 2006; Gros et al., 2007). Specific 
analyses of selected pesticides with emphasis on compounds used in rice fields in the delta region of the Ebro and further pesticides applied in the Brévilles Catchment (atrazine, desethyl- and deisopropyl-AT, isoproturon, chlortoluron, acetochlor, acetochlor ethanesulfonic and oxanilic acid) in water and soil were also developed (Barata et al., 2007; Eljarrat et al., 2005a; Hildebrandt et al., 2007).

Further new analytical methods have included a multiresidue method with liquid chromatography triple quadrupole and quadrupole time of flight mass spectromety for the determination of a wide range of pharmaceutical compounds in the environment (Gros et al., 2007; Peschka et al., 2007). Analyses have included anti-inflammatory drugs, antibiotics, $\beta$-blockers, lipid regulating agents, anti-histaminic and psychiatric drugs. In addition, new brominated flame-retardants (hexabromocyclododecane, decabromodiphenylethane) were detected in environmental samples of the Ebro Basin and led to the advanced modelling of these compounds in the food chain (Eljarrat et al., 2004, 2005a, b; Lacorte et al., 2006; Van Beusekom et al., 2006).

Further new analyses of persistent organic pollutants with a focus on polycyclic aromatic hydrocarbons (PAHs) from field deposition samplers and from sorption experiments were conducted (Barth et al., 2007c; Gocht et al., 2007a, b; Turner et al., 2006). A first calibration dataset for validation of passive adsorption cartridges as a new method for time-integrated surface water sampling of organic compounds was also developed. This can become highly important for river water sampling where low concentrations of compounds in surface waters still need to be analysed for flux considerations over longer time periods. Passive samplers were also further developed for additional compound groups and environmental compartments. This work produced new data about the performance of passive air sampler designs for validation of, for instance, brominated flame retardants (Harner et al., 2006).

\subsection{Transport, storage and turnover of organic and metal pollutants: a summary from the subproject BIOGEOCHEM}

Part of the team demonstrated the importance of colloids, dissolved organic matter and the role of micro organisms for contaminant mobility in floodplains (Abelmann et al., 2005; Weber et al., 2007; Voegelin et al., 2007). They applied a combined approach of field lysimeters, laboratory microcosm and flow-through experiments. Flooding enabled the direct field sampling of contaminants including copper, cadmium, lead and polyaromatic hydrocarbons. The group further developed protocols for the sampling of water-dispersible particles under reducing canditions and their characterization using TEM and X-ray absorption spectroscopy (Weber et al., 2007).

Furthermore, sorption properties of selected field samples yielded an extensive list of solute descriptors for a wide range of organic compounds to enable rapid prediction of soil-water distribution coefficients. Laboratory methods for sorption dynamics of polar compounds were also extended and led to the determination of sorption isotherms of 21 polar and non-polar compounds. This is crucial to determine how rapidly pollutants can be released into the water and helps to quantify their mobility and availability for biodegradation. Another column experiment to evaluate movement of pesticides through rocks was performed and further coal petrography microscopy of carbon phases in soil and sediment samples helped to define the phases in soils and sediments that are responsible for sorption.

Statistical analyses further determined the impacts of temperature, $\mathrm{pH}$, gas phase and microbial activity on inorganic pollutants in the soil- and groundwater zone. The resulting equilibrium constants served to characterise soils and aquifer material of the Dommel, Flémalle and Gallego sites as examples for successful applications. Further studies of bacterial biodiversity were performed with statistical analyses for soil incubations and provided new relationships between the bacterial community structure and, for instance, arsenic turnover while combined lysimeter experiments under vegetation showed preferential flow of lead via particle transport (Joubert et al., 2007; Vanbroekhoven et al., 2007).

Microbiological work revealed new functional activities and composition of microbial communities throughout the Brévilles, Danube, Ebro and Elbe areas by applying new molecular markers that respond to system perturbations such as changes in redox conditions, water saturation and pollution. Laboratory model systems including microcosms and sediment columns are currently applied to simulate various perturbations under environmental conditions such as changing temperature, redox, water saturation and influx of pollutants as typical environmental changes.

One important new finding of the microbiological team is that the sum of all nonylphenol (NP) isomers can serve as an indicator of estrogen pollution in sediments to characterise estrogenic activity response (de Weert et al., 2008). They studied the bioavailability and biodegradability of NP

Table I. Residual microwave assisted extractable nonylphenol (NP) or estrogenic activity in estradiol-equivalents (EEQ) after biodegradation as fraction of the total microwave assisted extractable amount in the original sediments.

\begin{tabular}{lll}
\hline & NP & EEQ \\
\hline Original sediment & $100 \pm 6 \%$ & $100 \pm 43 \%$ \\
After & $3 \pm 0.5 \%$ & $6 \pm 2 \%$ \\
biodegradation & & \\
\hline
\end{tabular}

over time in contaminated river sediment of a tributary of the Ebro River. The bioavailable fraction was collected with Tenax $\mathrm{TA}^{\circledR}$ beads, and biodegradation was determined in aerobic batch experiments. The presence of NP was analyzed chemically using GC-MS and indirectly as estrogenic potency using an in vitro reporter gene assay (ER $\alpha$-luc assay). Our study revealed that $95 \%$ of the total extractable NP in the sediment desorbed quickly into the water phase. By aerobic biodegradation, the total extractable NP concentration and the estrogenic activity were reduced with respectively $97 \pm 0.5 \%$ and $94 \pm 2 \%$, 


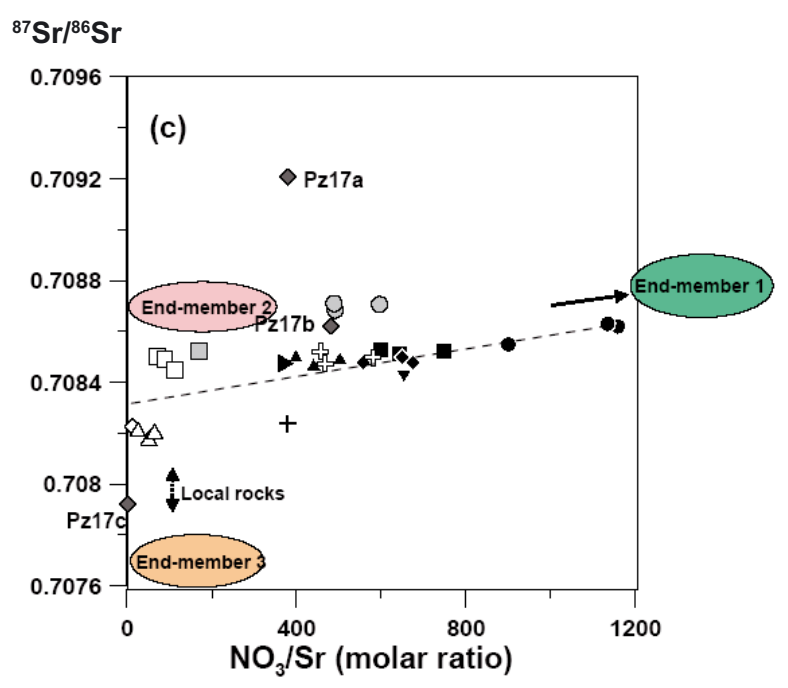

Figure 3. $\mathrm{Sr}$ isotopes $\left({ }^{87} \mathrm{Sr} /{ }^{86} \mathrm{Sr}\right)$ versus the $\mathrm{NO}_{3} / \mathrm{Sr}$ molar ratio of all piezometers and springs of the Brévilles Catchment. Samples plot between two natural sources (end-members $1 \& 2$ ) and the anthropogenic source (fertilizers, end-member 1).

(cf. Tab. I). This shows that the easily biodegradable fraction equals the potential bioavailable fraction. Furthermore, $43 \%$ of the estrogenic activity in the total extractable fraction, as detected in the ER $\alpha$-luc assay, could be explained by the present NP concentration. This indicates that other estrogenic compounds must be present and that their bioavailability and aerobic degradation should be similar to that of NP. With this, the use of NP as an indicator compound to monitor estrogenic activity in Ebro sediment was proposed.

The microbiological team of AquaTerra also quantified degradation of a variety of organic compounds including atrazine, nonylphenol, DDT, vinylchloride, 1,2-dichloroethane, chlorinated benzenes, brominated flame retardants, polycyclic aromatic compounds (PAH), atrazine, isoproturon, acetochlor under laboratory conditions. Biodegradation rates capacity may work differently in the field, for which a novel compilation of changes in compound specific stable isotope ratios was introduced as a suitable monitoring tool to quantify degradation rates of organic compounds (Barth et al., 2007c; Morasch et al., 2007). In the field dechlorinating bacteria were detected and quantified. Especially Dechalococcoides were detected in the presence of baloorganic pollutants. This suggents that a high abundonce of these bacteria can be used as an indication of contamination.

\subsection{Pollutant input, fluxes and exchanges between compartments}

On local scales such as for the Brévilles Catchment interviews with local farmers helped to assess present and past pesticide inputs, while groundwaters were analysed for the same compounds on a monthly basis (Baran et al., 2007). Furthermore, interaction between water bodies in the Brévilles

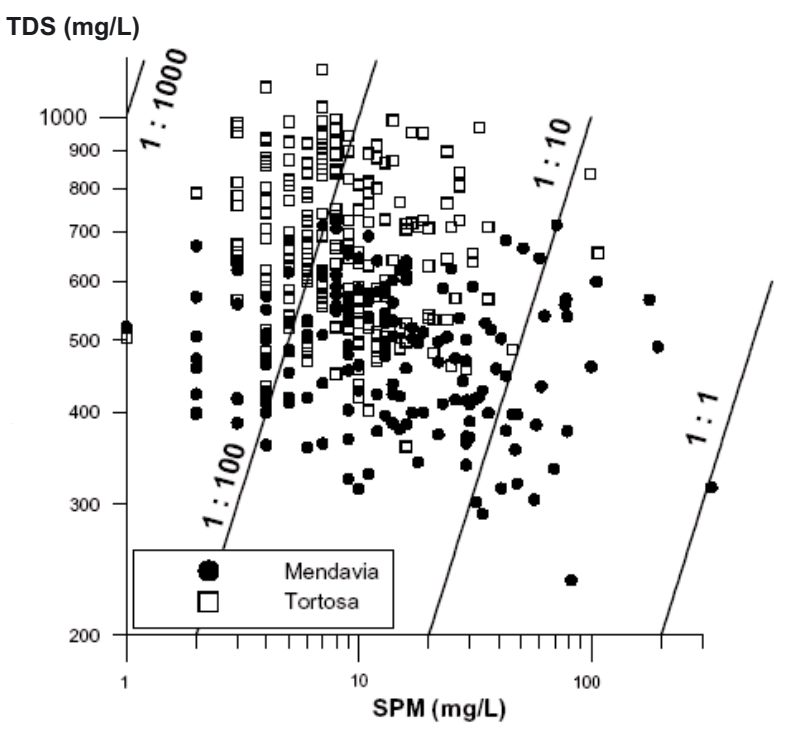

Figure 4. Plot of the total dissolved solids (TDS) and suspended particulate matter (SPM), all in $\mathrm{mg} \mathrm{L}^{-1}$ for the Ebro River at Mendavia $(n=172)$ and Tortosa $(n=217)$. This reflects the influence of dams and their hampering of suspended matter exportations in Tortosa at the outlet of the basin, where dissolved exportations largely dominate.

catchment could associate $\mathrm{Sr}$ from anthropogenic sources via unique isotope ratios and demonstrated the capacity of $\mathrm{Sr}$ isotopes to trace fertilizer contributions versus natural sources (Fig. 3).

Another local study characterised temperature- and integral pumping tests for pollutant transfer determinations in the Mulde Area in the Elbe Basin (Kalbus et al., 2007; Schmidt et al., 2006). This led to definitions of spatial heterogeneity of ground- and stream water interactions that were also confirmed by isotope tracing with strontium and water isotopes (Petelet-Giraud et al., 2007).

On larger scales, sampling campaigns for major ions, trace elements and isotopes in the Ebro River, combined with historical data, led to new quantifications of long-term suspended and dissolved matter (Négrel et al., 2007). This work is best summarised in Figure 4 that evaluates suspended matter concentrations versus total dissolved solids to outline influences of dams.

The Meuse River basin was investigated through a new lake sediment core, recording the major flood events, and the study of present suspended matter exportations in order to compare the present and past SPM fluxes at the scale of the Meuse Basin. A sub-catchment of the Meuse, the Dommel, was also studied for its surface- and groundwater dynamics with novel methods including strontium, boron, lithium, cadmium, zinc and lead isotopes. This helped to decipher the anthropogenic sources (urban, industrial) and their behaviour at the basin scale. Work within the FLUX subproject was further accompanied by monitoring of suspended matter transport by novel acoustic methods. A new prototype near-bed hydrophone array provided high-resolution data during in-situ 


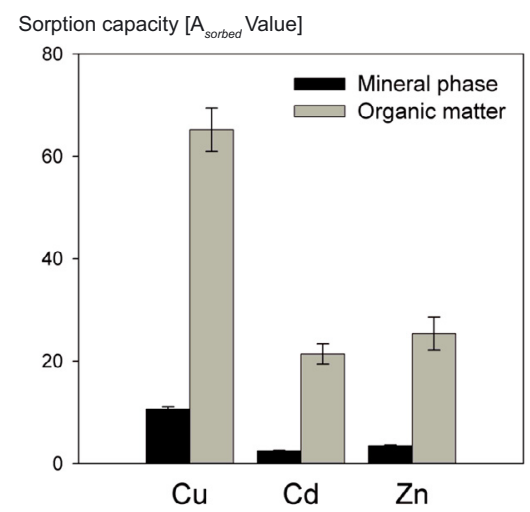

Figure 5. Sorption capacities of soil phases for selected heavy metals in a Cambisol (37\% clay, 41\% silt, $2.6 \%$ organic C, soil pH 5.7). $\mathrm{A}_{\text {sorbed }}\left[\mathrm{mmol}^{2} \mathrm{~kg}^{-1} \mathrm{~L}^{-1}\right]$ represents a calculated parameter from sorption isotherms.

experimentation under high flux conditions (Hermand and Holland, 2005; Hermand et al., 2006). Further tests are now considered at selected AquaTerra sites and are expected to develop into a fully-coupled sediment transport model that is leading for sediment transport in the field.

For comparison between basins, passive air and deposition data were also collected for the areas of Brévilles, Danube, Ebro, Elbe and Meuse catchments to cover a total period of 24 months (Barth et al., 2007c). Sampling of soil and water was finalized for the same areas and samples were prepared for polyaromatic hydrocarbon analyses.

\subsection{Temporal spatial soil and groundwater developments and their numerical tracing}

Sediment, water and soil samples were sampled in the above-mentioned river basins and studied by several new techniques in order to identify trends in the fate and risk potential of contaminants. Sorption studies with floodplain soils pointed to an increasing sorption capacity with progressing soil formation (e.g. (Graf et al., 2007). Retention of naphthalene and heavy metals was found to be mainly influenced by soil $\mathrm{pH}$ and soil organic matter (Lair et al., 2007a, b). Trends for metal behavior in soils are presented in Figure 5.

Other novel live biological monitoring approaches involved earthworms and revealed differences between selected floodplain soils in terms of feeding activity and weight loss (Bleeker and van Gestel, 2007; Vijver et al., 2007). On the other hand, breakdown of leaves from the Dommel Area (Meuse Basin) showed differences between sampling sites that are probably linked to macro fauna abundance and site properties. Other new bioassay studies with larvae and other sediment habitat in the Elbe System also found decreases of contaminant bioavailability through ageing in sediment-water systems, which may be counteracted by increasing temperatures, thus giving important indications for impact assessment under changing climate (Hsu et al., 2007).
In this context physical models were developed for deterministic trend analysis in groundwater and associated reactive transport models (Barth et al., 2007b; Visser et al., 2007). Several tools for trend detection and forecasting for groundwater quality were developed. These included tools based on backscaling of time series using the recharge time, which was determined by ${ }^{3} \mathrm{H} /{ }^{3} \mathrm{He}$ age dating.

Field campaigns in the Brévilles Catchment initiated parameterisation of pesticide leaching to simulate atrazine and water fluxes in the unsaturated zone and in the aquifer (Morvan et al., 2006). On the other hand, the Geer Basin in the Meuse comprised a groundwater flow and solute transport model from input of groundwater sampling for dating techniques including the tritium method to relate the nitrate concentration in the aquifer to water ages (Brouyère, 2006). This model was further developed for nitrate transport as an example of highly soluble diffuse inputs (Batlle Aguilar et al., 2007; Brouyère et al., 2007; Orban et al., 2005).

In addition to this, a several new theories in the field of machine learning (Schölkopf and Smola, 2002; Tipping, 2001) and artificial neural networks were investigated and applied to rainfall-runoff modelling in the Gallego Catchment in the Ebro Basin (Bürger et al., 2007). Further interpolation studies on environmental screening data was carried out using diverse network types and new work was also initiated for pattern recognition and clustering of a new soil parameter data set across Europe.

\subsection{Modeling hydrological and pollutant transport and software development}

Modeling efforts in AquaTerra addressed relevant flow and transport processes at scales ranging from centimetres to hundreds of kilometres. At the smallest scale, one-dimensional models of preferential transport have been developed that account for the mobility of small soil particles and contaminants in macro-pores with initial focus on cadmium transport (Dohnal et al., 2006; Dusek et al., 2006). At the local scale the MARTHE 3D code was applied to model preferential flow and mass transport in the Brévilles Catchment (Thiery and Amraoui, 2001; Vanderborght et al., 2005). This complemented a finite differences model with inputs from the HYDRO and FLUX subprojects. In addition, the time resolution of the soil-atmosphere boundary fluxes was found to be a significant factor when modeling the mobility of dissolved contaminants in soils.

At the hillslope scale, a conceptual framework was developed and tested for modeling subsurface flow and transport and in the Meuse-Dommel area were data collection and models comparisons were completed. Furthermore, a new database for the Meuse-Geer Basin was established including data preparation and geometrical set-up of data. Analysis of hillslope-scale processes in small, snow dominated, catchments was accomplished by using the GEOtop model (Zanotti et al., 2004), together with a comprehensive study on soil moisture dynamics and travel time distribution (Botter et al., 2007). 
On larger scales a comprehensive modeling framework for solute transport was developed and applied to the Dese catchment in Italy (Botter et al., 2005, 2006; Rinaldo et al., 2006a, b). Based on this theoretical framework the GEOTRANSF model was developed and applied to the Brenta and Gallego catchments. The first is located in north-eastern Italy, while the second is a tributary of the Ebro River in Spain. This work improves our understanding of anthropogenic effects, such as reservoir operation and withdrawals for agricultural purposes, on the hydrological system and enables to distinguish between the effects of climate change and water use. Developments of new modules considering nitrogen cycling and a specific salinisation mechanism were also started (Botter et al., 2006). The Ebro Basin is now planned as a target for an entire basin model and the salinisation issue will be addressed within the Gallego catchment in collaboration with INTEGRATOR and FLUX teams.

The modelling effort was supplemented by the development of unified simulation tools for coupled surface/subsurface flow models that uses different approaches and constitutes a software toolbox for environmental modelling (Beinhorn et al., 2005; Kalbacher et al., 2005; Kolditz and Bauer, 2004; Kolditz et al., 2005, 2006). An application linking soil and groundwater compartments was finalised in the Beerze-Reusel area, a catchment of about $300 \mathrm{~km}^{2}$ in the Meuse Basin (Kolditz et al., 2007). This provides a regional hydrologic soil model for groundwater recharge patterns using various infiltration scenarios. Such work provides new toolboxes to help linking environmental compartments in modelling through implemented codes (Geo-Sys/RockFlow). For the Meuse-Geer subcatchment, a concept for multi-scale modelling was also started and the team developed a new interface for coupling surface and subsurface flow. With this step, extremely fine resolutions of soils ( $5 \mathrm{~cm}$ vertical) can now be modeled for several hundreds of $\mathrm{km}^{2}$ by parallel computation techniques to address highly resolved regional groundwater recharge patterns in heterogeneous soils.

\subsection{Integrating socio-economic outcomes and policy interactions}

The INTEGRATOR team identified key environmental issues through stakeholder feedback from the four main river basins studied within AquaTerra (Ebro, Meuse, Elbe, Danube). A first economic analysis was performed on selected case studies derived from this work, leading to new initial conceptual models. The new approach proposed to determine how best to address the challenge to assist decision making for a range of end-users at various levels with reference to work from the INTEGRATOR and EUPOL teams. In a common work effort by the INTEGRATOR team all deliverables produced in AquaTerra up to February 2007 were broadly reviewed and assessed with respect to their environmental, social and economic characteristics (basin location, scale, key pressures in the selected areas, type of contaminant, for example). In order to enhance the delivery of AquaTerra key findings and achievements and to bring them to potential end- users, a delivery/integration methodology was developed. This consisted of interviewing subproject- and work package leaders by phone, using simultaneously questionnaires to provide a structure to the interview. This helped to determine which key findings were produced by AquaTerra to date, to understand how these key results could address river basin management issues and identify potential end-user types who could benefit from these results. The process helped to define the Knowledge \& Data and Tools produced by AquaTerra and their applicability with respect to relevant issues in river basin management.

A further key objective of the INTEGRATOR project was the identification of the inter-relationships between AquaTerra and other scientific projects. Interviews with AT work package leaders, along with internet searches and conference workshops, have identified where potential and real collaborations exists. It is important to note that AquaTerra does not exist in isolation and that there is an overall awareness of where and how interactions take place. While at a European scale such work is truly the role of a Co-ordination Action, the identification of interaction between projects has been a valuable exercise and has helped to support the proposals for an interlinked web-based resource. This is realised through a website that will present the project information in a format of value to target end users (technical, management and policy users connected with the implementation of the Water Framework Directive to 2015 and beyond). It will also provide a means of interconnecting with other project websites in the field of water management with the aim to create a wider resource of added value to end-users, projects and scientists.

The EUPOL scientific framework was a first attempt to link outputs of AquaTerra to the needs of policy through a series of generic policy questions identified through brainstorm meetings with policy makers from across Europe. Since this work was produced, the EUPOL team has summarised their ongoing work in a review that deals with the challenges of linking scientific knowledge to river basin management policy (Slob et al., 2007).

\section{CONCLUSION}

The AquaTerra work shows that the understanding of organic and inorganic pollutant turnover, storage and transport in soils, sediments, ground- and surface water needs interdisciplinary and international approaches that enable the combination of techniques and transgression of compartments. The main challenge remains the improvement of understanding of the large-scale behaviour of pollutants with the complexity and heterogeneity of the systems involved. Particularly, links between compartments such as the atmosphere, soils, groundand surface water, as well as sediments, have interfaces where the steepest biogeochemical gradients can be expected. For instance, within basins, floodplains are perhaps the most interesting sites for dynamic biogeochemical research as they largely control pollutant storage and release. They also link the atmosphere, soils, ground- and surface waters and further research and exchange of knowledge needs to focus on such 
exemplatory dynamic areas in order to evaluate how pollutants are turned over and under which water level and associated redox, $\mathrm{pH}$ and temperature conditions they may be mobilised or immobilised.

For catchment- and basin-wide results the detailed pesticide study in the Brévilles area has shown that application of diffuse pollutants even in small areas leads to highly complex responses in ground- and surface water systems. Turnover, storage and degradation times appear much longer than expected and may affect even small systems such as the Brévilles catchment for decades to centuries. When scaling up to larger areas, even longer transport times can be anticipated because of the greater distances and generally slower groundwater transport. It becomes clear that response times of the soil, groundand surface water system can be much longer than measures taken to stop pollutant and nutrient loadings. They often range between decades and millennia and therefore comprise much longer time spans than policy instruments such as the Water Framework or the Groundwater Directives currently take into account. Such instruments must therefore adapt to these time frames in order to efficiently implement environmental protection.

On the other hand, long time frames may also offer advantages. For instance, microbiological turnover in the subsurface may have more time to remove pollutants before they are transported to vulnerable receptors such as drinking water aquifers or organisms in ecosystems. Further research is necessary to determine which metabolites would be expected under such a scenario and whether they are harmful and in which time frames they develop and disappear.

The MONITOR subproject has demonstrated that we are able to determine the status quo of environmental systems with ever increasing accuracy and detail of analytical techniques. This allows better estimation of distributional patterns and the evaluation of sources and fluxes of pollutants. On the other hand, when process-relevant studies are based in the laboratory alone, they yield crucial first information on the environmental behaviour of pollutants. Nonetheless, these laboratory results need to either adapt to the field (which remains a major challenge) or demand evaluation with great care when transferring results to field sites. Some first field-based techniques, such as stable isotope quantifications of turnover of organic compounds in the field, are beginning to show the extent to which processes such as natural attenuation actually take place in natural environments.

For field investigations, our understanding of pollutant dynamics is often still limited by too sparse sample densities in space and time. While individual sampling campaigns often yield highly localised information and snapshots of long-term processes, new integral monitoring techniques might offer future solutions and trends in this respect. With this, our initial results of AquaTerra showed hotspot showed and diffuse pollution patterns that the evaluation of large-scale and long-term pollutant behaviour needs to be further resolved with temperature changes and mixtures of pollutants, changing geochemical and microbiological conditions. More field studies under real conditions are necessary to feed results into reactive trans- port models. For the above, networks of passive samplers may hold the key for taking laboratory results to the field.

In terms of potential climate change impacts, not explicitly considered by either the Water Framework or Groundwater Directives, results from the HYDRO sub-project have shown that it is necessary to consider the predictions of more than one climate model when trying to assess future impacts due to the uncertainties in model response. Initial results from impact studies suggest that in Europe we can expect increases in heavy rainfall, particularly in winter months, with a potential knock-on effect on flooding, and increases in long term (southern Europe) and short-term (northern Europe) drought frequencies and intensities. These changes to climate will have important impacts on the diffusion and degradation of pollutants in space and time that are just at the start of their exploration. AquaTerra is providing one of the first attempts to link climate change impacts on the soil, sediment, ground- and surface water system at the catchment scale to management and policy decisions. However, more research is needed in this area to provide guidance for management of the effects of climate change on already stressed river basins in Europe.

Overall, work within AquaTerra leads to recommendations that crop controls and fertilisers need to be applied with care and under consideration of the consequences for receiving water systems that often serve as drinking water supplies. We developed models to quantify export of nutrients by the hyporheic zone and further studies are underway in order to better understand the impact of the river network structure on cycling of nutrients, and at the smaller scale the interplay between riparian and hyporheic areas along the river system.

Acknowledgements: This work was supported by the European Union FP6 Integrated Project AquaTerra (Project No. GOCE 505428) under the thematic priority, sustainable development, global change and ecosystems and also further supported by a Grant from the Ministry of Science, Research and the Arts of Baden Wuertemberg (AZ33-7533.18-15-02/80) to Johannes Barth and Peter Grathwohl.

\section{REFERENCES}

Abelmann K., Kleineidam S., Knicker H., Grathwohl P., Koegel-Knabner I. (2005) Sorption of HOC in soils with carbonaceous contamination: Influence of organic-matter composition, J. Plant Nutr. Soil Sci. 168, 293-306.

Baborowski M., Buttner O., Morgenstern P., Kruger F., Lobe I., Rupp H., Tumpling W.v. (2007) Spatial and temporal variability of sediment deposition on artificial-lawn traps in a floodplain of the River Elbe, Environ. Pollut. 148, 770-778.

Baran N., Mouvet C., Negrel P. (2007) Hydrodynamic and geochemical constraints on pesticide concentrations in the groundwater of an agricultural catchment (Brévilles, France), Environ. Pollut. 148, 729-738.

Barata C., Damasio J., Lopez M.A., Kuster M., De Alda M.L., Barcelo D., Riva M.C., Raldua D. (2007) Combined use of biomarkers and in situ bioassays in Daphnia magna to monitor environmental hazards of pesticides in the field, Environ. Toxicol. Chem. 26, 370-379.

Barcelo D., Brix R., Farre M. (2006) Monitoring and managing river pollutants. Report on the 3rd SWIFT-WFD Workshop, in collaboration with AquaTerra, entitled "Towards operational monitoring programmes and protocols for implementation of the Water 
Framework Directive; Chemical analysis and data interpretation of priority and emerging pollutants in the river basin", Barcelona, Spain, 15-16 May 2006, TrAC - Trend. Anal. Chem. 25, 743-747.

Barth J.A.C., Fowler H.J. (2005) AquaTerra, a new Integrated Project in FP 6: active since June 2004, Land Contamination Reclamation, Clean-up Regeneration Bull. 13, 201-205.

Barth J.A.C., Grathwohl P., Jones K.C. (2007a) Introduction to AquaTerra special Issue "AquaTerra: Pollutant behavior in the soil, sediment, ground, and surface water system", Environ. Pollut. 148, 693-694.

Barth J.A.C., Kalbus E., Schmidt C., Bayer-Raich M., Reinstorf F., Schirmer M., Thiéry D., Dubus I.G., Gutierrez A., Baran N., Mouvet C., Petelet-Giraud E., Négrel P., Banton O., Batlle Aguilar J., Brouyère S., Goderniaux P., Orban P., Rozemeijer J.C., Visser A., Bierkens M.F.P., Van der Grift B., Broers H.P., Marsman A., Klaver G., Slobodnik J., Grathwohl P. (2007b) Selected groundwater studies of EU project AquaTerra leading to large-scale basin considerations, Water Practice Technol. 2, 1-8.

Barth J.A.C., Steidle D., Kuntz D., Gocht T., Mouvet C., von Tumpling W., Lobe I., Langenhoff A., Albrechtsen H.J., Janniche G.S., Morasch B., Hunkeler D., Grathwohl P. (2007c) Deposition, persistence and turnover of pollutants: First results from the EU project AquaTerra for selected river basins and aquifers, Sci. Total Environ. 376, 40-50.

Batlle Aguilar, J., Orban P., Dassargues A., Brouyère S. (2007) Identification of groundwater quality trends in a chalk aquifer threatened by intensive agriculture in Belgium, Hydrogeol. J. 15, 1615-1627.

Beinhorn M., Dietrich P., Kolditz O. (2005) 3-D numerical evaluation of density effects on tracer tests, J. Contam. Hydrol. 81, 89-105.

Bernhard R., Verkleij J.A.C., Nelissen H.J.M., Vink J.P.M. (2005) Plantspecific responses to zinc contamination in a semi-field lysimeter and on hydroponics, Environ. Pollut. 138, 100-108.

Bleeker E.A.J., van Gestel C.A.M. (2007) Effects of spatial and temporal variation in metal availability on earthworms in floodplain soils of the river Dommel, The Netherlands, Environ. Pollut. 148, 824-832.

Blenkinsop S., Fowler H.J. (2007a) Changes in drought characteristics for Europe projected by the PRUDENCE regional climate models, Int. J. Climatol. 27, 1595-1610.

Blenkinsop S., Fowler H.J. (2007b) Changes in drought frequency, severity and duration for the British Isles projected by the PRUDENCE regional climate models, J. Hydrol. 342, 50-71.

Botter G., Bertuzzo E., Bellin A., Rinaldo A. (2005) On the Lagrangian formulations of reactive solute transport in the hydrologic response, Water Resour. Res. 41, 1-13.

Botter G., Settin T., Marani M., Rinaldo A. (2006) A stochastic model of nitrate transport and cycling at basin scale, Water Resour. Res. 42, W04415, doi: 10.1029/2005WR004599.

Botter G., Porporato A., Rodriguez-Iturbe I., Rinaldo A. (2007) Basinscale soil moisture dynamics and the probabilistic characterization of carrier hydrologic flows: Slow, leaching-prone components of the hydrologic response, Water Resour. Res. 43, W02417, doi: 10.1029/2006WR005043.

Brouyère S. (2006) Modelling the migration of contaminants through variably saturated dual-porosity, dual-permeability chalk, J. Contam. Hydrol. 82, 195-219.

Brouyère S., Batlle Aguilar J., Goderniaux P., Dassargues A. (2007) A new tracer technique for monitoring groundwater fluxes: The Finite Volume Point Dilution Method, J. Contam. Hydrol. 95, 121-140.

Bürger C.M., Kolditz O., Fowler H.J., Blenkinsop S. (2007) Future climate scenarios and rainfall-runoff modelling in the Upper Gallego catchment (Spain), Environ. Pollut. 148, 842-854.
Burton A., Kilsby C.G., Fowler H.J., Cowpertwait P.S.P., O'Connell P.E. (submitted) RainSim: A spatial temporal stochastic rainfall modelling system, Environ. Modell. Softw.

de Weert J., De la Cal A., van den Berg H., Murk A., Langenhoff A., Rijnaarts H., Grotenhuis H. (2008) Bioavailability and biodegradation, of nonylphenol in sediment determined with chemical and bioanalysis, Environ. Toxicol. Chem. 27 (4).

Dohnal M., Dušek J., Vogel T., Herza J., Tachecí P. (2006) Analysis of Soil Water Response to Grass Transpiration, Soil Water Res. (CAZV) 1, 85-98.

Dusek J., Vogel T., Lichner L., Čipáková A., Dohnal M. (2006) Transport of cadmium in macroporous soil during heavy rainstorm, Biologia (Springer) 61, 251-254.

Eljarrat E., De La Cal A., Raldua D., Duran C., Barcelo D. (2004) Occurrence and Bioavailability of Polybrominated Diphenyl Ethers and Hexabromocyclododecane in Sediment and Fish from the Cinca River, a Tributary of the Ebro River (Spain), Environ. Sci. Technol. 38, 2603-2608.

Eljarrat E., De La Cal A., Larrazabal D., Fabrellas B., Fernandez-Alba A.R., Borrull F., Marce R.M., Barcelo D. (2005a) Occurrence of polybrominated diphenylethers, polychlorinated dibenzo-pdioxins, dibenzofurans and biphenyls in coastal sediments from Spain, Environ. Pollut. 136, 493-501.

Eljarrat E., De La Cal A., Raldua D., Duran C., Barcelo D. (2005b) Brominated flame retardants in Alburnus alburnus from Cinca River Basin (Spain), Environ. Pollut. 133, 501-508.

Eljarrat E., Barcelo D. (2006) Quantitative analysis of polychlorinated nalkanes in environmental samples, tr AC- Trend. Anal. Chem. 25, 421-434.

Fowler H.J., Blenkinsop S., Tebaldi C. (2007a) Linking climate change modelling to impacts studies: recent advances in downscaling techniques for hydrological modelling, Int. J. Climatol. 27, 1547-1578.

Fowler H.J., Ekstrom M., Blenkinsop S., Smith A.P. (2007b) Estimating change in extreme European precipitation using a multimodel ensemble, J. Geophys. Res.-Atmos. 112.

Fowler H.J., Ekström M., Blenkinsop S., Smith A.P. (2007c) Estimating change in extreme European precipitation using a multi-model ensemble, J. Geophys. Res.-Atmos. 112.

Gerzabek M.H., Barcelo D., Bellin A., Rijnaarts H.H.M., Slob A., Darmendrail D., Fowler H.J., Négrel P., Frank E., Grathwohl P., Kuntz D., Barth J.A.C. (2007) The integrated project AquaTerra of the EU sixth framework lays foundations for better understanding of river-sediment-soil-groundwater systems, J. Environ. Manage. 84, 237-243.

Gocht T., Klemm O., Grathwohl P. (2007a) Long-term atmospheric bulk deposition of polycyclic aromatic hydrocarbons (PAHs) in rural areas of Southern Germany, Atmos. Environ. 41, 1315-1327.

Gocht T., Ligouis B., Hinderer M., Grathwohl P. (2007b) Accumulation of polycyclic aromatic hydrocarbons in rural soils based on mass balances at the catchment scale, Environ. Toxicol. Chem. 26, 591600 .

Graf M., Lair G.J., Zehetner F., Gerzabek M.H. (2007) Geochemical fractions of copper in soil chronosequences of selected European floodplains, Environ. Pollut. 148, 788-796.

Gros M., Petrovic M., Bascelo D. (2007) Wastewater treatement plants as a pathway for aquatic contamination by pharmaceuticals in the ebro river basin (northeast Spain), Environ. Toxicol. Chem. 26, 15531562 .

Harner T., Bartkow M., Holoubek I., Klanova J., Wania F., Gioia R., Moeckel C., Sweetman A.J., Jones K.C. (2006) Passive air sampling for persistent organic pollutants: Introductory remarks to the special issue, Environ. Pollut. 144, 361-364. 
Hermand J.P., Holland C.W. (2005) Geoacoustic characterisation of finegrained sediments using single and multiple reflection data, Mar. Geophys. Res. 26, 267-274.

Hermand J.P., Meyer M., Asch M., Berrada M. (2006) Adjoint-based acoustic inversion for the physical characterization of a shallow water environment (a), J. Acoust. Soc. Am. 119, 3860-3871.

Hildebrandt A., Lacorte S., Barceló D. (2006) Sampling of water, soil and sediment to trace organic pollutants in a river basin scale, Anal. Bioanal. Chem. 386, 1075-1088.

Hildebrandt A., Lacorte S., Barcelo D. (2007) Assessment of priority pesticides, degradation products, and pesticide adjuvants in groundwaters and top soils from agricultural areas of the Ebro river basin, Anal. Bioanal. Chem. 387, 1459-1468.

Hsu P., Matthai A., Heise S., Ahlf W. (2007) Seasonal variation of sediment toxicity in the Rivers Dommel and Elbe, Environ. Pollut. 148, $817-823$.

Joubert A.V.P., Lucas L., Garrido F., Joulian C., Jauzein M. (2007) Effect of temperature, gas phase composition, $\mathrm{pH}$ and microbial activity on $\mathrm{As}, \mathrm{Zn}, \mathrm{Pb}$ and $\mathrm{Cd}$ mobility in selected soils in the Ebro and Meuse Basins in the context of global change, Environ. Pollut. 148, $749-758$.

Kalbacher T., Wang W., McDermott C., Kolditz O., Taniguchi T. (2005) Development and application of a CAD interface for fractured rock, Environ. Geol. 47, 1017-1027.

Kalbus E., Schmidt C., Bayer-Raich M., Leschik S., Reinstorf F., Balcke G.U., Schirmer M. (2007) New methodology to investigate potential contaminant mass fluxes at the stream-aquifer interface by combining integral pumping tests and streambed temperatures, Environ. Pollut. 148, 808-816.

Klaver G., van Os B., Negrel P., Petelet-Giraud E. (2007) Influence of hydropower dams on the composition of the suspended and riverbank sediments in the Danube, Environ. Pollut. 148, 718-728.

Kolditz O., Bauer S. (2004) A process-orientated approach to compute multi-field problems in porous media, Int. J. Hydroinformatics 6 , 225-244.

Kolditz O., Beinhorn M., Liedl R. (2005) An object-oriented groundwater/river model, IAHS-AISH Publication, pp. 531-539.

Kolditz O., Du Y., Burger C., Delfs J., Kuntz D., Beinhorn M., Hess M., Wang W., van der Grift B., te Stroet C. (2007) Development of a regional hydrologic soil model and application to the Beerze-Reusel drainage basin, Environ. Pollut. 148, 855-866.

Labandeira A., Eljarrat E., Barcelo D. (2007) Congener distribution of polybrominated diphenyl ethers in feral carp (Cyprinus carpio) from the Llobregat River, Spain, Environ. Pollut. 146, 188-195.

Lacorte S., Raldua D., Martinez E., Navarro A., Diez S., Bayona J.M., Barcelo D. (2006) Pilot survey of a broad range of priority pollutants in sediment and fish from the Ebro river basin (NE Spain), Environ. Pollut. 140, 471-482.

Lair G.J., Gerzabek M.H., Haberhauer G. (2007a) Retention of copper, cadmium and zinc in soil and its textural fractions influenced by long-term field management, Eur. J. Soil Sci. 58, 1145-1154.

Lair G.J., Gerzabek M.H., Haberhauer G. (2007b) Sorption of heavy metals on organic and inorganic soil constituents, Environ. Chem. Lett. $5,23-27$.

Lucas L., Joubert A., Garrido F., Joulian C., Breeze, D., Jauzein M. (2006) Behavior of toxic elements in agricultural and industrial vadose zone soils of three Ebro and Meuse river basin areas in the context of global climate change, Geochim. Cosmochim. Acta, 70, A373.

Marani M., Zanetti S. (2007) Downscaling rainfall temporal variability, Water Resour. Res. 43, WO9415.
Morasch B., Hohener P., Hunkeler D. (2007) Evidence for in situ degradation of mono-and polyaromatic hydrocarbons in alluvial sediments based on microcosm experiments with 13C-labeled contaminants, Environ. Pollut. 148, 739-748.

Morvan X., Mouvet C., Baran, N., Gutierrez, A. (2006) Pesticides in the groundwater of a spring draining a sandy aquifer: temporal variability of concentrations and fluxes, J. Contam. Hydrol. 87, 176-190.

Navarro A., Tauler R., Lacorte S., Barcelo D. (2006) Chemometrical investigation of the presence and distribution of organochlorine and polyaromatic compounds in sediments of the Ebro River Basin, Anal. Bioanal. Chem. 385, 1020-1030.

Négrel P., Roy S., Petelet-Giraud E., Millot R., Brenot A. (2007) Longterm fluxes of dissolved and suspended matter in the Ebro River Basin (Spain), J. Hydrol. 342, 249-260.

Orban P., Brouyere S., Corbeanu H., Dassargues A. (2005) Large-scale groundwater flow and transport modelling: Methodology and application to the Meuse Basin, Belgium, IAHS-AISH Publication, pp. 489-495.

Peschka M., Petrovic M., Knepper T.P., Barcelo D. (2007) Determination of two phototransformation products of bentazone using quadrupole time-of-flight mass spectrometry, Anal. Bioanal. Chem. 388, 1227-1234.

Petelet-Giraud E., Negrel P., Gourcy L., Schmidt C., Schirmer M. (2007) Geochemical and isotopic constraints on groundwater-surface water interactions in a highly anthropized site, The Wolfen/Bitterfeld megasite (Mulde subcatchment, Germany), Environ. Pollut. 148, $707-717$.

Poot A., Gillissen F., Koelmans A.A. (2007) Effects of flow regime and flooding on heavy metal availability in sediment and soil of a dynamic river system, Environ. Pollut. 148, 779-787.

Quiros L., Raldúa D., Navarro A., Casado M., Barceló D., Piña B. (2007) A non-invasive test of exposition to toxicants: quantitative analysis of cytochrome p4501a1 expression in fish scales, Environ. Toxicol. Chem. 26, 2179-2186.

Ratola N., Lacorte S., Alves A., Barcelo D. (2006) Analysis of polycyclic aromatic hydrocarbons in pine needles by gas chromatographymass spectrometry Comparison of different extraction and clean-up procedures, J. Chromatogr. A 1114, 198-204.

Rinaldo A., Botter G., Bertuzzo E., Uccelli A., Settin T., Marani M. (2006a) Transport at basin scales: 2. Applications, Hydrol. Earth Syst. Sc. 10, 31-48.

Rinaldo A., Botter G., Bertuzzo E., Uccelli A., Settin T., Marani M. (2006b) Transport at basin scales: 1. Theoretical framework, Hydrol. Earth Syst. Sc. 10, 19-29.

Roulier S., Baran N., Mouvet C., Stenemo F., Morvan X., Albrechtsen H.J., Clausen L., Jarvis N. (2006) Controls on atrazine leaching through a soil-unsaturated fractured limestone sequence at Brevilles, France, J. Contam. Hydrol. 84, 81-105.

Rozemeijer J.C., Broers H.P. (2007) The groundwater contribution to surface water contamination in a region with intensive agricultural land use (Noord-Brabant, The Netherlands), Environ. Pollut. 148, 695706.

Schmidt C., Bayer-Raich M., Schirmer M. (2006) Characterization of spatial heterogeneity of groundwater-stream water interactions using multiple depth streambed temperature measurements at the reach scale, Hydrol. Earth Syst. Sci. Discussions 3, 1419-1446.

Schölkopf B., Smola A. (2002) Learning with Kernels: Support Vector Machines, Regularization, Optimization and Beyond. MIT Press, Cambridge, MA, USA.

Slob A.F.L., Rijnveld M., Chapman A.S., Strosser P. (2007) Challenges of linking scientific knowledge to river basin management policy: AquaTerra as a case study, Environ. Pollut. 148, 867-874.

Terrado M., Barcelo D., Tauler R. (2006) Identification and distribution of contamination sources in the Ebro river basin by chemometrics modelling coupled to geographical information systems, Talanta 70, 691-704. 
Terrado M., Kuster M., Raldūa D., Lopez De Alda M., Barcelo D., Tauler R. (2007a) Use of chemometric and geostatistical methods to evaluate pesticide pollution in the irrigation and drainage channels of the Ebro river delta during the rice-growing season, Anal. Bioanal. Chem. 387, 1479-1488.

Terrado M., Kuster M., Raldua D., M., L.d.A., Barcelo D., Tauler R. (2007b) Evaluation of Pesticides Pollution in the Irrigation and Drainage Channels of the Ebro River Delta during the Growing Season of Rice Using Chemometric and Geostatistical Methods, Anal. Bioanal. Chem. (in press).

Thiery D., Amraoui N. (2001) Hydrological modelling of the Saone Basin sensitivity to the soil model, Phys. Chem. Earth Pt B 26, 467-472.

Tipping M. (2001) Sparse Bayesian learning and the relevance vector machine, J. Mach. Learn. Res. 1.

Turner J., Albrechtsen H.J., Bonell M., Duguet J.P., Harris B., Meckenstock R., McGuire K., Moussa R., Peters N., Richnow H.H., Sherwood-Lollar B., Uhlenbrook S., van Lanen H. (2006) Future trends in transport and fate of diffuse contaminants in catchments, with special emphasis on stable isotope applications, Hydrol. Proc. 20, 205-213.

Van Beusekom O.C., Eljarrat E., Barcelo D., Koelmans A.A. (2006) Dynamic modeling of food-chain accumulation of brominated flame retardants in fish from the Ebro river basin, Spain, Environ. Toxicol. Chem. 25, 2553-2560.

Vanbroekhoven K., Van Roy S., Gielen C., Maesen M., Ryngaert A., Diels L., Seuntjens P. (2007) Microbial processes as key drivers for metal (im)mobilization along a redox gradient in the saturated zone, Environ. Pollut. 148, 759-769.

Vanderborght J., Kasteel R., Herbst M., Javaux M., Thiery D., Vanclooster M., Mouvet C., Vereecken H. (2005) A set of analytical benchmarks to test numerical models of flow and transport in soils, Vadose Zone J. 4, 206-221.

Vijver M.G., Vink J.P.M., Miermans C.J.H., van Gestel C.A.M. (2007) Metal accumulation in earthworms inhabiting floodplain soils, Environ. Pollut. 148, 132-140.

Vink J.P.M., Meeussen J.C.L. (2007) BIOCHEM-ORCHESTRA: A tool for evaluating chemical speciation and ecotoxicological impacts of heavy metals on river flood plain systems, Environ. Pollut. 148, 833-841.

Visser A., Broers H.P., van der Grift B., Bierkens M.F.P. (2007) Demonstrating trend reversal of groundwater quality in relation to time of recharge determined by $3 \mathrm{H} / 3 \mathrm{He}$, Environ. Pollut. 148, 797807.

Voegelin A., Weber F.-A., Kretzschmar R. (2007) Distribution and speciation of as around roots in a contaminated riparian floodplain soil: Micro-XRF element mapping and EXAFS spectroscopy, Geochim. Cosmochim. Acta. 71, 5804-5820.

Weber F.A., Voegelin A., Voegi R., Kretzschmar R. (2007) Formation of copper sulfide nanoparticles in a flooded soil: Potential for colloid facilitated transport of contaminants, Geochim. Cosmochim. Acta 71, A1094-A1094.

Zanotti F., Endrizzi S., Bertoldi G., Rigon R. (2004) The GEOTOP snow module, Hydrol. Process. 18, 3667-3679. 
Copyright of Agronomy for Sustainable Development is the property of EDP Sciences and its content may not be copied or emailed to multiple sites or posted to a listserv without the copyright holder's express written permission. However, users may print, download, or email articles for individual use. 